\title{
Tularaemia in Berlin - two independent cases in travellers returning from central Anatolia, Turkey, February 2011
}

A Schubert (Amadeus.Schubert@lageso.berlin.de) ${ }^{1}$, W Splettstoesser ${ }^{2}$, J Bätzing-Feigenbaum ${ }^{1}$

1. Infectious Disease Protection and Epidemiology Unit, State Office for Health and Social Affairs (LAGeSo), Federal State of Berlin, Berlin, Germany

2. German Reference Laboratory for Tularaemia, Bundeswehr Institute of Microbiology, Munich, Germany

Citation style for this article

Schubert A, Splettstoesser W, Bätzing-Feigenbaum J. Tularaemia in Berlin - two independent cases in travellers returning from central Anatolia, Turkey, February 2011.

Euro Surveill. 2011;16(18):pii=19860. Available online: http://www.eurosurveillance.org/ViewArticle.aspx?Articleld=19860

Article published on 5 May 2011

Tularaemia, though rare, has recently been increasingly reported in Germany. Most cases are indigenous infections. This report describes two epidemiologically independent infections with Francisella tularensis subspecies holarctica detected in Berlin in February 2011 that were acquired in central Anatolia, Turkey. In Turkey, there have been repeated tularaemia outbreaks since 2000 and the disease should therefore be considered as a differential diagnosis in travellers returning from that country.

\section{Case description and clinical diagnosis}

In March 2011, two travellers returning from Turkey, both in their twenties, were diagnosed with Francisella tularensis in Berlin, Germany. Both had independently stayed in Turkey between end 2010 and early 2011 to visit their respective families in Yozgat, central Anatolia, $218 \mathrm{~km}$ east of Ankara in the Ak mountains. The population of Yozgat in 2008 was 71,768, the province counted 492,127 inhabitants [1].

Both patients had similar general symptoms including fever, pharyngitis, otitis and cervical lymphadenopathy, but showed different locations of the ulcerations specific for tularaemia. Both infections were characterised by slow and subacute clinical progression. Patient 1 stayed in Turkey between 25 July 2010 and 29 January 2011. Onset of symptoms was on 15 December 2010. Patient 2 had been in Turkey from 24 December 2010 to 8 January 2011 and fell ill on 10 January 2011.

The patients were diagnosed in mid-February 2011, after their return to Berlin. Patient 1 was diagnosed with oropharyngeal tularaemia, Patient 2 with the ulceroglandular form. The latter form is the most common expression of tularaemia. Typical symptoms are ulcerations next to the inoculation site linked with regional, often purulent inflammation of the lymph nodes. In advanced stages with extended lymphadenitis colli and suppurative ulcerations of multiple lymph nodes, the definite identification of the primary inoculation site is difficult to achieve. The exact description of primary clinical symptoms, however, is very important to elucidate the transmission routes and further epidemiological links $[2,3]$.

Further interviews with Patient 2 revealed additional epidemiological information: the patient and one of his siblings both fell ill on 10 January 2011, and a further sibling two days later. However, these two patients remained in Turkey.

\section{Laboratory confirmation}

The detection of the pathogen by bacterial culture is difficult, special media are needed and growth is generally slow. More sensitive laboratory methods like PCR are only available in a small number of specialised laboratories $[2,3]$. Laboratory confirmation for the two cases was available on 4 March. The German national reference laboratory for tularaemia in Munich could detect $F$. tularensis subspecies holarctica (Jellison type B) via PCR in both cases. Specific DNA sequences were detected in the purulent puncture material of affected lymph nodes.

A serological diagnosis done previously in the hospital in Berlin for Patient 2 had shown IgG and IgM antibodies against $F$. tularensis lipopolysacharides. The infection in Patient 1 was not proved serologically in the hospital, but could be confirmed through specific antibodies in the national reference laboratory.

\section{Public health implications}

After the diagnoses were confirmed, information was immediately reported according to the World Health Organization's WHO International Health Regulations (IHR) to the Robert Koch-Institute (RKI). At that time, no recent data were accessible about the tularaemia situation in Turkey. Data about tularaemia infections related to recent travel to Turkey or to neighbouring countries were not found. 
Turkish citizens are one of the larger populations with migration background in Germany. At the end of 2010 nearly $2 \%$ of the German population were Turkish $(1,629,480$ inhabitants) [4]. In Berlin at the end of 2009, $3 \%$ of the population were Turkish citizens $(108,000$ inhabitants) [5]. In addition, an unknown number of German citizens of Turkish origin still have intensive contacts with their families in Turkey and frequently travel there.

Therefore, the health authorities in all 16 German federal states were informed on 8 March during the weekly epidemiological telephone conference (EpiLag), since more imported infections in international travellers could not be excluded. To get further data about the situation in Turkey, but also to alert other countries, the RKI informed the Turkish IHR focal point and the WHO Regional Office for Europe about the infections. Furthermore, information was sent to the Early Warning and Response System (EWRS) of the European Union. On the national level the decision was made to involve the German National Centre for Biological Security at the RKI because the pathogen $F$. tularensis is classified as a potential biological risk agent. Overall, the risk of further transmission and the threat to public health in Germany was estimated as low.

\section{Epidemiological considerations}

In the past years tularaemia outbreaks in Europe were documented in Norway [6,7], Sweden [8], Spain [9] and the UN Administered Province of Kosovo in accordance with Security Council Resolution 1244 of 1999 [10]. Parts of Turkey have been strongly affected by the reemergence of tularaemia and a number of outbreaks have been published since 2000 [11-16]. In Germany, tularaemia cases are rare, however, increasing numbers have been reported since 2007 . Some travel-associated tularaemia cases have been reported in Germany (10 of 74 cases between 2001 and 2009), but only one case dating back to 2003 originated from Turkey $[17,18]$.
The tularaemia cases reported in Germany since 2001 and the countries where the infections were acquired are shown in the Figure.

Through information exchange via the national German and Turkish IHR Focal Points with the General Directorate of Primary Health Care in the Turkish Ministry of Health, further details were provided about the current situation in Turkey and possible sources of infection (personal communication: Dr. Tamer Sami Pelitli, 18 March 2011). More than a hundred tularaemia cases were reported to the national reference laboratories from central parts of Turkey, especially in the Yozgat province in 2010. The cases had been confirmed serologically and through PCR in two reference laboratories in Ankara and Bursa, Turkey. Based on this information the Ministry of Health of Turkey has implemented an action plan to fight the spread of tularaemia in 2010. This action plan is focussed on the rehabilitation of water systems. As a promising result the number of reported tularaemia cases decreased in 2011 compared with the previous years. After being informed by the German IHR Focal Point about the two cases in Berlin, the Turkish Ministry of Health started active surveillance work in the Yozgat province, but has not yet detected new transmission risks for tularaemia.

In both cases from Berlin the source of infection could not be identified conclusively. However, based on the available epidemiological information, the most probable cause of the two infections is consumption of contaminated water during the stay in a region of Turkey endemic for tularaemia. Transmission has often been associated with decentralised drinking water supply like cisterns and insufficiently treated surface water [15]. The clinical presentation at least in one of the patients diagnosed in Berlin supports this suggestion. Oropharyngeal tularaemia is presumably related to oral ingestion of the pathogen.

\section{FIGURE}

Human tularaemia cases reported in Germany, by country of infection 2001-2011 (n=111)

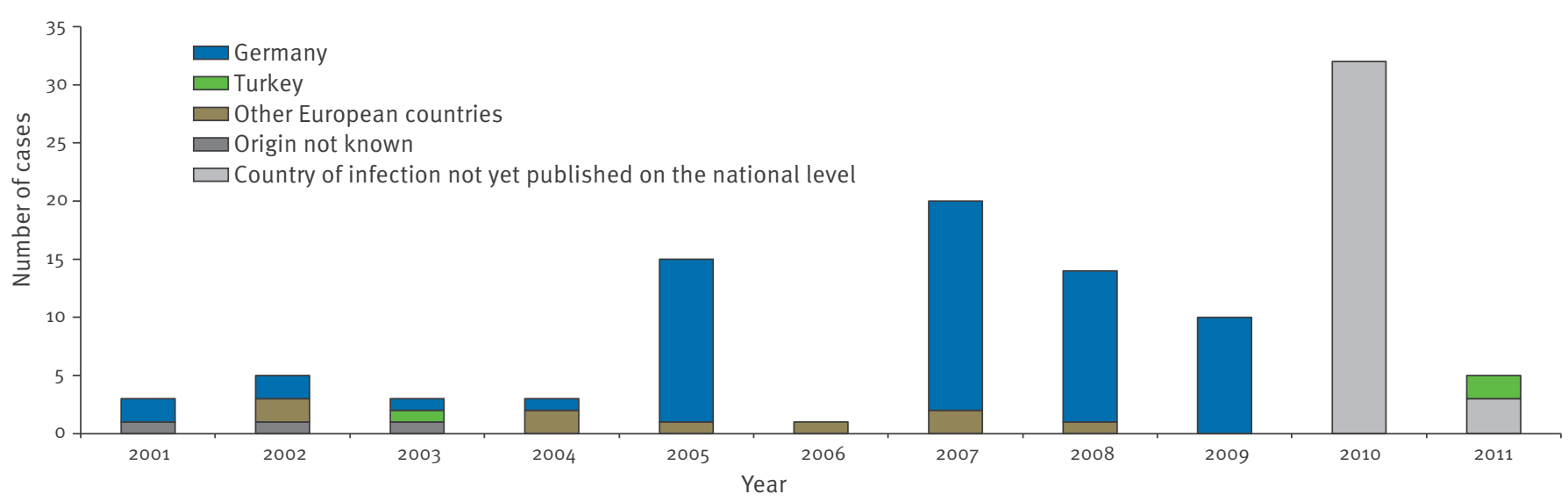

Data recorded on 3 May $2011[17,18]$ according to the national Protection Against Infection Act (Infektionsschutzgesetz, IfSG). 


\section{Clinical considerations}

Due to the relatively unspecific general symptoms of tularaemia and the variety of the primary disease patterns (depending on the route of infection) clinical diagnosis is not easy. Therefore, early suspicion of tularaemia depends on a precise medical history and epidemiological data regarding in particular travel history, animal contacts, occupation, and insect bites. The diagnosis should subsequently be confirmed through sensitive biomolecular methods like PCR with direct identification in blood, lymph node punctuates or wound swabs, and specific serological tests, both of which are available in specified laboratories.

Early diagnosis allows immediate therapy with effective antibiotics like doxycycline or fluoroquinolones, which can be combined with aminoglycosides in severe cases. Drugs used empirically in many cases of lymphadenitis of uncertain origin are cephalosporins, amoxicilline/clavulanate, and macrolides which, however, are not effective against tularaemia. Sometimes even surgical interventions to eliminate a suspected tumour are performed during infection with $F$. tularensis. In these cases, tularaemia is frequently diagnosed only retrospectively by histo-pathological examination and/or by detection of $F$. tularensis-specific antibodies.

Clinical physicians should currently be aware of possible infections with $F$. tularensis in travellers from some regions of Turkey. In case of clinical signs suggestive of tularaemia, effective diagnostic methods should not be delayed, since diagnostic delay can easily result in extended suffering of the patient. Besides addressing the public health aspects of the disease, epidemiology plays a major role in supporting the early and effective clinical diagnosis and treatment of tularaemia.

\section{Acknowledgement}

The authors would like to thank the District Health Offices Berlin-Mitte and Berlin-Neukölln and Mirko Faber and the German IHR-Team (Robert Koch-Institute, Berlin) for their support.

\section{References}

1. Adrese Dayalı Nüfus Kayıt Sistemi (ADNKS) Sonuçları 2008. [Address-based population registration system for 2008] Ankara: Turkish Institute for Statistics. [Accessed 8 March 2011]. Turkish. Available from: http://tuikapp.tuik.gov.tr/ adnksdagitapp/adnks.zul

2. Tularämie, Hasenpest (Francisella tularensis). [Tularaemia, rabbit fever (Francisella tularensis)]. Berlin: Robert KochInstitute; Dec 2001. German. Available from: http://www. rki.de/cln_109/nn_504578/DE/Content/InfAZ/T/Tularaemie/ $\mathrm{MBL}$ _- Tularaemie.html

3. Grunow R, Priebe H-S. Tularämie - Zum Vorkommen in Deutschland. Analyse auf der Basis der Meldedaten von 1949 bis 2006. [Tularaemia - occurrence in Germany. Analysis based on reporting dates from 1949 to 2006]. Epidemiologisches Bulletin. 2007;(7):55-6. German. Available from: http://www. rki.de/cln_109/nn_264978/DE/Content/Infekt/EpidBull/Arc hiv $/ 2007 / 07,07$, templateld $=$ raw, property=publicationfile pdf/07_07.pdf
4. Ausländische Bevölkerung am 31.12.2010 nach Geschlecht und ausgewählten Staatsangehörigkeiten. [Foreign population on $31 / 12 / 2010$ by sex and selected nationalities]. Wiesbaden: Statistisches Bundesamt. [Accessed 3 May 2011]. Available from: http://www.destatis.de/jetspeed/portal/cms/Sites/ destatis/Internet/DE/Content/Statistiken/Bevoelkerung/ MigrationIntegration/AuslaendischeBevoelkerung/Tabellen/ Content75/Geschlecht,templateld=renderPrint.psml

5. Statistisches Jahrbuch Berlin 2010. [Annual statistics report Berlin 2010]. Potsdam: Amt für Statistik BerlinBrandenburg; 2010. German. Available from: http://www. statistik-berlin-brandenburg.de/PRODUKTE/jahrbuch/jb2010/ BE_Jahrbuch_2010.pdf

6. Brantsæter AB, Krogh T, Radtke A, Nygard K. Tularaemia outbreak in northern Norway. Euro Surveill. 2007;12(13): pii=3165. Available from: http://www. eurosurveillance.org/ViewArticle.aspx?Articleld=3165

7. Larssen KW, Afset JE, Heier BT, Krogh T, Handeland K, Vikøren T, et al. Outbreak of tularaemia in central Norway, January to March 2011. Euro Surveill. 2011;16(13):pii=19828. Available from: http://www.eurosurveillance.org/ViewArticle. aspx?Articleld $=19828$

8. Wik 0: Large tularaemia outbreak in Värmland, central Sweden, 2006. Euro Surveill. 2006;11(38):pii=3052. Available from: http://www.eurosurveillance.org/ViewArticle. aspx?Articleld $=3052$

9. Martín C, Gallardo MT, Mateos L, Vian E, Garcia MJ, Ramos J, et al. Outbreak of tularaemia in Castilla y León, Spain. Euro Surveill. 2007;12(45):pii=3302. Available from: http://www. eurosurveillance.org/ViewArticle.aspx?Articleld=3302

10. Robert Koch Institute. Zu einem Tularämie-Ausbruch im Kosovo. [On a tularaemia outbreak in Kosovo]. Epidemiologisches Bulletin. 2000;(18):146-7. German. Available from: http://www.rki.de/cln_160/nn_196444/DE/ Content/Infekt/EpidBull/Archiv/2000/18_00,templateld=raw, property=publicationFile.pdf/18_oo.pdf

11. Gürcan S, Eskiocak M, Varol G, Uzun C, Tatman-Otkun M, Sakru $\mathrm{N}$, et al. Tularemia re-emerging in European part of Turkey after 60 years. Jpn J Infect Dis. 2006;59(6):391-3 Jpn J Infect Dis. 2006 Dec;59(6):391-3.

12. Celebi G, Baruönü F, Ayoğlu F, Cinar F, Karadenizli A, Uğur MB, et al. Tularemia, a reemerging disease in northwest Turkey: epidemiological investigation and evaluation of treatment responses. Jpn J Infect Dis. 2006;59(4):229-34.

13. Sahin M, Atabay HI, Bicakci Z, Unver A, Otlu S. Outbreaks of tularemia in Turkey. Kobe J Med Sci. 2007;53(1-2):37-42

14. Ozdemir D, Sencan I, Annakkaya AN, Karadenizli A, Guclu E, Sert E, et al. Comparison of the 2000 and 2005 outbreaks of tularemia in the Duzce region of Turkey. Jpn J Infect Dis. 2007;60(1):51-2

15. Willke A, Meric M, Grunow R, Sayan M, Finke EJ, Splettstösser $W$, et al. An outbreak of oropharyngeal tularaemia linked to natural spring water. J Med Microbiol. 2009;58(Pt 1):112-6

16. Meric M, Sayan M, Dundar D, Willke A. Tularaemia outbreaks in Sakarya, Turkey: case-control and environmental studies. Singapore Med J. 2010;51(8):655-9

17. Infektionsepidemiologische Jahrbücher 2001-2009. [Annual reports on the epidemiology of notifiable infectious diseases 2001-2009]. Berlin: Robert Koch Institute. [Accessed 3 May 2011]. German. Available from: http://www.rki.de/cln_169/ nn 196882/DE/Content/Infekt/Jahrbuch/Jahrbuecher/ jahrbuecher_node.html?_nnn=true

18. SurvStat@RKI. Berlin: Robert Koch-Institute. [Accessed 3 May 2011]. German. Available from: http://www.rki.de/cln_178/ nn_196658/DE/Content/Infekt/SurvStat/survstat_inhalt. html?_nnn=true 